\title{
A new record of Paramylodon harlani (Owen 1840) (Xenarthra, Pilosa, Mylodontidae) from the late Pleistocene of Valsequillo, Puebla, with comments on its paleobiogeography and paleoecology in Mexico
}

Nuevo registro de Paramylodon harlani (Owen 1840) (Xenarthra, Pilosa, Mylodontidae) del Pleistoceno tardío de Valsequillo, Puebla, con comentarios sobre su paleogeografía y paleoecología en México

Gerardo Carbot-Chanona $^{1, *}$, Eduardo Jiménez-Hidalgo ${ }^{2}$, Francisco J. Jiménez-Moreno ${ }^{3}$, Enrique Benítez-Gálvez ${ }^{4}$

\begin{abstract}
${ }^{1}$ Museo de Paleontología "Eliseo Palacios Aguilera", Dirección de Paleontología, Secretaría de Medio Ambiente e Historia Natural. Calzada de Las Personas Ilustres s/n, Tuxtla Gutiérrez, Chiapas, Mexico.
\end{abstract}

${ }^{2}$ Laboratorio de Paleobiología, Instituto de Recursos, Campus Puerto Escondido, Universidad del Mar. Ciudad Universitaria Puerto Escondido, 71985 , Oaxaca, Mexico.

${ }^{3}$ Universidad Angelópolis, Calle 3 Ote. 1603, Colonia Azcarate, 72000, Puebla, Puebla.

${ }^{4}$ Independent researcher. Puebla de Zaragoza, Puebla, Mexico.

* Corresponding author: (G. Carbot-Chanona)gfcarbot@gmail.com

\section{ABSTRACT}

Paramylodon harlani was a large ground sloth recorded across North America, from Canada to Mexico. In Mexico, it is known from several late Pleistocene localities, but most of these records just mention the taxon in passing and few specimens have been described or illustrated. In this work, we describe a left tibia from the Valsequillo Basin, Puebla state. Its morphology and measurements allowed us to identify it as Paramylodon harlani, adding a new record for Mexico. In Mexico, P. harlani occurred mainly in the Trans-Mexican Volcanic Belt, central Mexico, with some records in the north and southeastern part of the country. Most localities are located between 1500 to 2000 m.a.s.l. Paleoenvironmental and paleoclimatic inference in some localities of Mexico where $P$. harlani occurred, showed heterogenous vegetation dominated by grasslands, and agree with the preferred habitat proposed for this species based on localities in the United States. This indicates that $P$. harlani could inhabit different environments, from grasslands to more wooded areas, and this adaptation allowed it to extend its range from the north to the southeast of Mexico.

Manuscript received: August 25, 2019

Corrected manuscript received: October 20, 2019

Manuscript accepted: November 5,2019

Peer Reviewing under the responsibility of Universidad Nacional Autónoma de México.

This is an open access article under the CC BY-NC-SA license (https://creativecommons.org/licenses/by-nc-sa/4.0/)
Keywords: Paramylodon, Quaternary, late Pleistocene, biogeographic corridors, habitat.

\section{RESUMEN}

Paramylodon harlani fue un perezoso terrestre de gran tamaño distribuido a través de América del Norte, desde Canadá hasta México. En México se conoce en varias localidades del Pleistoceno tardio, pero la mayoría de esos reportes son sólo menciones y poco material ha sido descrito o ilustrado. En este trabajo describimos una tibia izquierda proveniente de la Cuenca de Valsequillo, Puebla; la morfología y medidas permiten referirla a Paramylodon harlani, con lo que se añade un nuevo registro para México. Nuestros resultados muestran que P. harlani se encontraba principalmente en la Faja Volcánica Transmexicana, en el centro de México, con algunos registros en el norte y sureste. El mayor número de localidades se ubica entre los 1500 a 2000 msnm. Las inferencias paleoambientales y paleoclimáticas de algunas de las localidades donde se encuentra $\underline{\text { P. harlani, muestran que }}$ existió vegetación heterogénea dominada por pastizales, lo que concuerda con los hábitats propuestos para la especie en localidades de EUA. Esto indica que P. harlani podía habitar diferentes ambientes, desde pastizales hasta zonas más arboladas, y es posible que esa adaptación le haya permitido extenderse desde el norte al sureste de México.

Palabras clave: Paramylodon, Cuaternario, Pleistoceno tardío, Corredores biogeográficos, hábitat. 


\section{Introduction}

Ground sloths originated in South America in the late Eocene-early Oligocene and they had a broad geographic range in this subcontinent throughout the Cenozoic (McKenna et al., 2006; Gaudin and Croft, 2015). Extinct taxa were more diverse and had a broader spatial distribution range than today.

Four families of ground sloths reached North America in two principal migration events; first, Megalonychidae and Mylodontidae during the late Miocene, and later Megatheriidae, Mylodontidae and Nothrotheriidae during the Pliocene-Pleistocene interval, being an important part of the Great American Biotic Interchange (Marshall 1988; Webb, 1989, 2006). The record of ground sloths in the late Pleistocene of North America comprised taxa of the four families, the megathere Eremotherium laurillardi, the nothrothere $\mathcal{N}_{0}$ throtheriops shastensis; the megalonychids Megalonyx jeffersonii, Meizonyx salvadorensis, Xibalbaonyx oviceps, X. microcaninus, and Nohochichak xibalbahkah, as well as mylodont Paramylodon harlani (Webb and Perrigo, 1985; McDonald and De Iuliis, 2008; McDonald and Carranza-Castañeda, 2017; Stinnesbeck et al., 2017; 2018); the later species is well known from several Irvingtonian and Rancholabrean localities in North America (Kurtén and Anderson, 1980; McDonald and Naples, 2008).

The nomenclatural history of Paramylodon harlani is problematic. First, Owen (1840) erected the genus Mylodon, with the type species $M$. darwinii based on a complete mandible and teeth from South America. In the same paper, Owen erected the species M. harlani for material from Big Bone Lick, Kentucky, USA. Later, Brown (1903) described material from Hay Spring, Nebraska as Paramylodon nebraskensis, which he differentiated from Mylodon based on the number of upper teeth. However, Stock (1917) noted that the number of upper teeth is variable, due to the presence or absence of the first upper tooth, and synonymized Paramylodon with Mylodon. Kraglievich (1928) argued that the North American mylodontids belonged to the genus Paramylodon. Later, Simpson (1945) mentioned that the North American forms are not generically separated from the South American ones, and they should be referred as Glossotherium, instead of Mylodon, and in subsequent works the name Glossotherium harlani was used (e.g. Kurtén and Anderson, 1980; Polaco-Ramos, 1981). McDonald (1995) mentioned that due to the geographic isolation and separate evolution of North and South American lineages of mylodonts, the use of Paramylodon harlani for the Irvingtonian and Rancholabrean specimens from North America is recommended. Finally, McAfee (2009) provided morphologic and morphometric support for the separation between Glossotherium and Paramylodon, with the second as the valid genus for the Late Pleistocene specimens from North America.

Paramylodon harlani was a large ground sloth that reached a body mass between 1,587 to $1,990 \mathrm{~kg}$ (Lambert and Holling, 1998; Smith et al., 2003); its distribution extended across the North American subcontinent, from Canada to Guatemala (Woodburne, 1969; Churcher, 1984; McDonald and De Iuliis, 2008). In Mexico, P. harlani has been previously reported from the Irvingtonian of El Golfo local fauna, Sonora (McDonald, 2002), and the Rancholabrean localities of Cabo Colnett in northern Baja California; Bustamante Cave, Nuevo León (McDonald, 2002); Zacoalco and Chapala, Jalisco (Polaco-Ramos, 1981; Lucas, 2008); La Cinta-Portalitos, Michoacán-Guanajuato (Eng-Ponce, 2018); El Cedral, San Luis Potosí (Polaco-Ramos, 1981); Arroyo Cedazo, Aguascalientes (Mooser and Dalquest, 1975); Tequixquiac, Tlalnepantla and Valle de Bravo, Estado de Mexico (Freudenberg, 1921; Mones, 1971; Cristín-Ponciano and Montellano-Ballesteros, 2008); Mexico City (Mulleried, 1934); Cueva Encantada de Chimalacatlán, Morelos (Arroyo-Cabrales et al., 2004); Santa Cruz Aquiahuac, Tlaxcala (Polaco-Ramos, 1981); Valsequillo, Puebla (Pérez-Crespo et al., 2014); Morro de la Mancha, Veracruz (Barrañón-Salmón and Pérez-Rodríguez, 2017); Teapa, Tabasco (Polaco-Ramos, 1981), Actun Spukil, Yucatán (Arroyo-Cabrales and Polaco, 2003), Santiago 


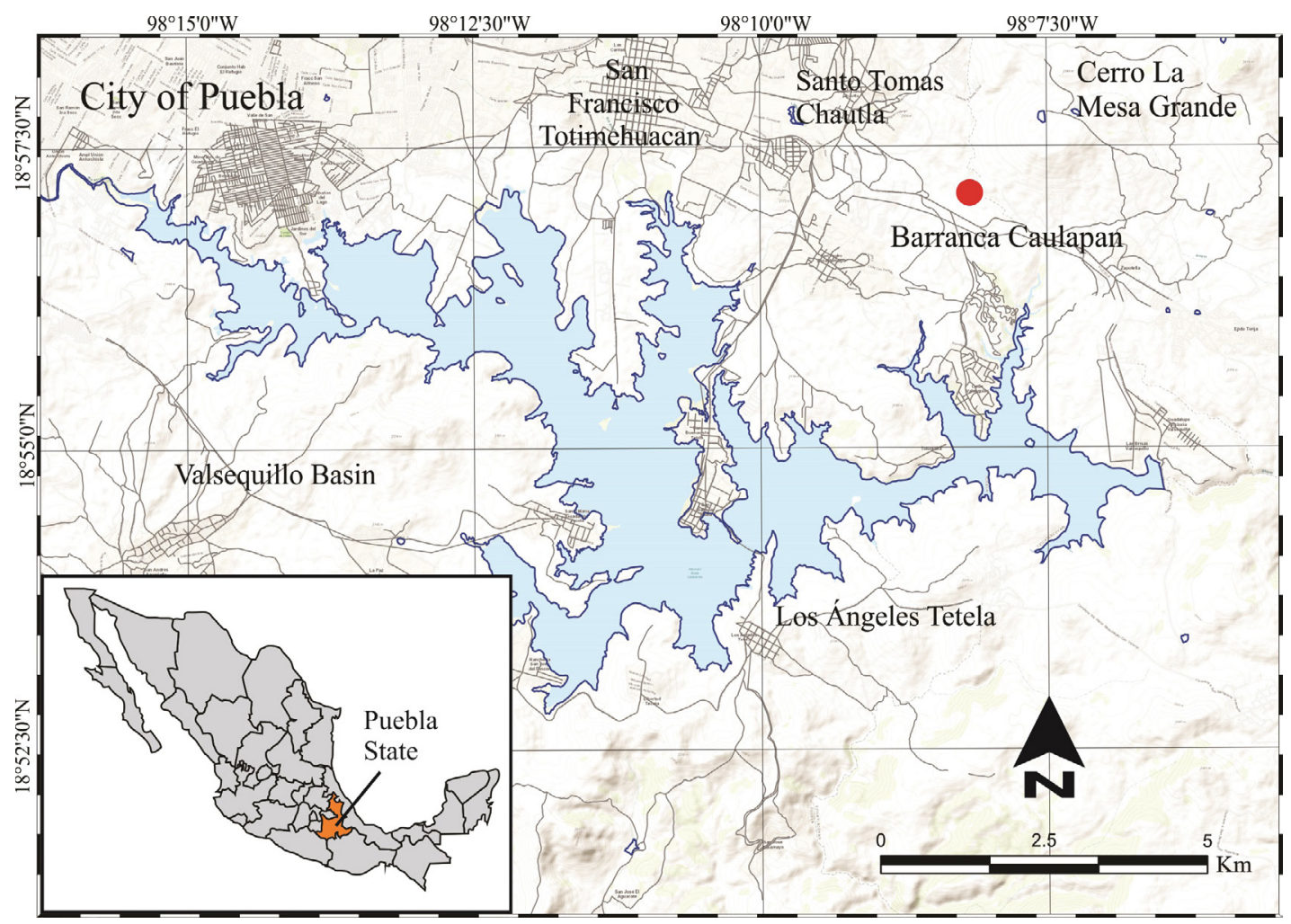

Chazumba, Oaxaca (Viñas-Vallverdú et al., 2017), and Villaflores, Chiapas (Carbot-Chanona and Gómez-Pérez, 2014).As demonstrated above, the record of $P$. harlani in Mexico is broad. Nevertheless, much of these records are only mentioned in passing and few of these specimens have been fully described or illustrated. The goal of this work is to describe a tibia of $P$. harlani, from the Valsequillo Basin, Puebla State and to discuss its paleoecology and paleobiogeography in Mexico.

\section{Study area and geological setting}

A sequence of alluvial deposits named Valsequillo Gravels crop out in the Valsequillo Basin (Metcalfe et al., 2016). In the Barranca Caulapan there is a $30 \mathrm{~m}$ thick exposure of the Valsequillo Gravels that has been radiocarbon dated between 9.15 to 38.9 ka (Gonzalez et al., 2006). Several mollusks and megafauna specimens, as well as evidence of human activity have been recovered in these sediments (Armenta Camacho, 1978; Pichardo,
1997; Stevens et al., 2012). The specimen described here comes from the El Balneario site, Barranca Caulapan, Cerro La Mesa Grande, in the Valsequillo Basin (1857’ N, 988' W, 2100 m.a.s.l.); which lies south of Puebla de Zaragoza city (Figure 1). The general stratigraphic sequence at the El Balneario site consists of 8 meters of fluvial sediments (the detailed stratigraphic description of this locality is in progress). The base of the section is constituted by gravel and coarse-grained sand of $1.1 \mathrm{~m}$ in thickness. Above follows a $0.7 \mathrm{~m}$ thick layer of medium-grained sand. Over this layer a sandy-silt layer of $1.30 \mathrm{~m}$ thick is present. Above $0.4 \mathrm{~m}$ of clay with organic matter contain fossil bones of mammoths, wolfs, bison, camels and horses recovered in association with the ground sloth tibia described here. Overlying there is a 1.4 $\mathrm{m}$ of sandy-silt., which is covered by a $0.6 \mathrm{~m}$ thick layer of clay with organic matter. Above, $2 \mathrm{~m}$ of sandy-silt layer is present. The top of the section is constituted by $0.5 \mathrm{~m}$ of fine-grained sand. The presence of Bison indicates a Rancholabrean North American Land Mammal Age. 


\section{Material and methods}

\subsection{STUDIED MATERIAL}

The specimen described consists of a complete left tibia collected with the traditional method of vertebrate paleontology, and is housed in the $\mathrm{Mu}$ seo de Paleontología "Eliseo Palacios Aguilera", under the number IHNFF-180, and it is registered in the Sistema Único de Registro Público de Monumentos y Zonas Arqueológicas e Históricas (Unique System of Public Registry of Monuments and Archaeological and Historical Zones) of the Instituto Nacional de Antropología e Historia, under the code 3117 P.F.10.

\subsection{MEASUREMENTS AND MATERIAL FOR COMPARISON}

The measurements follow McAfee (2007) and were made with a measuring tape (Figure 2). In order to taxonomically identify the specimen, it was compared to the tibia of large-sized taxa of ground sloths from the Late Pleistocene of North

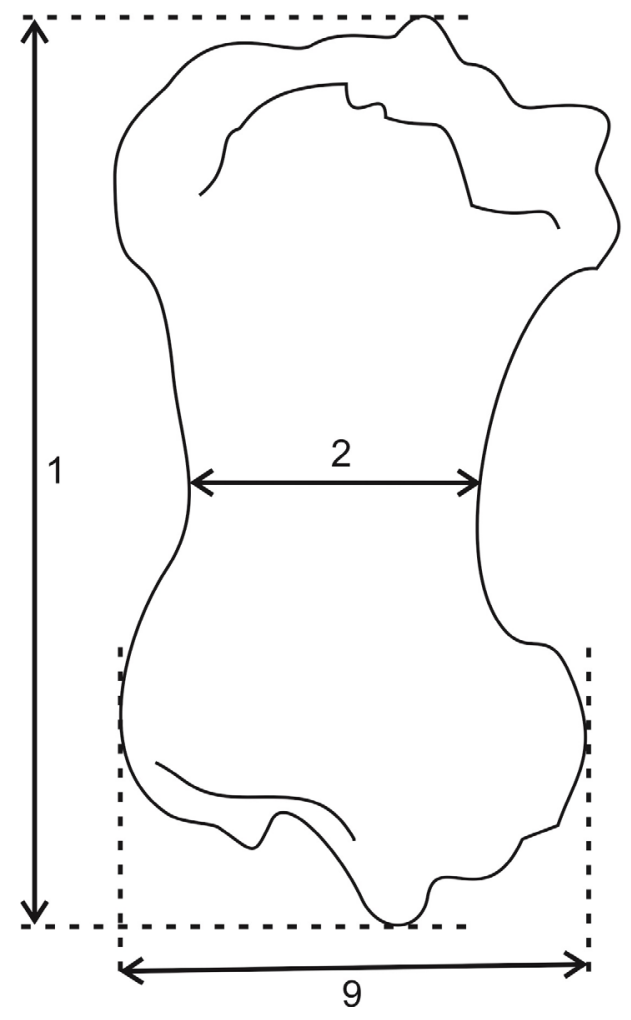

America, such as Eremotherium laurillardi, Megalonyx jeffersonii, and Nothrotheriops shastensis (Leidy, 1855; Stock, 1925; De Iuliis, 1996). We also compared it with Glossotherium tropicorum (De Iuliis et al., 2017), G. phoenesis (Cartelle et al., 2019), and G. robustum (specimens MLP 3-114, MLP 3-128, and MLP 35-III-10-1) of South America. Additionally, we compared it with the type specimen Paramylodon nebraskensis (=Paramylodon harlani) housed in the American Museum of Natural History under the number AMNH 2780.

\subsubsection{MEASUREMENTS ABBREVIATIONS}

1, Greatest length (GL); 2, mediolateral minimum width of the diaphysis in the midshaft $(\mathrm{MnW}) ; 3$, mediolateral width of medial condyle (MWMC); 4, anteroposterior width of medial condyle (AWMC); 5, mediolateral width of lateral condyle (MWLG); 6, anteroposterior width of lateral condyle (AWLG); 7, mediolateral width of proximal end across the condyles (PW); 8, intercondylar width (ICW); 9, mediolateral width of distal end (DW); 10, anteroposterior width of distal articular surface (AWDAS).
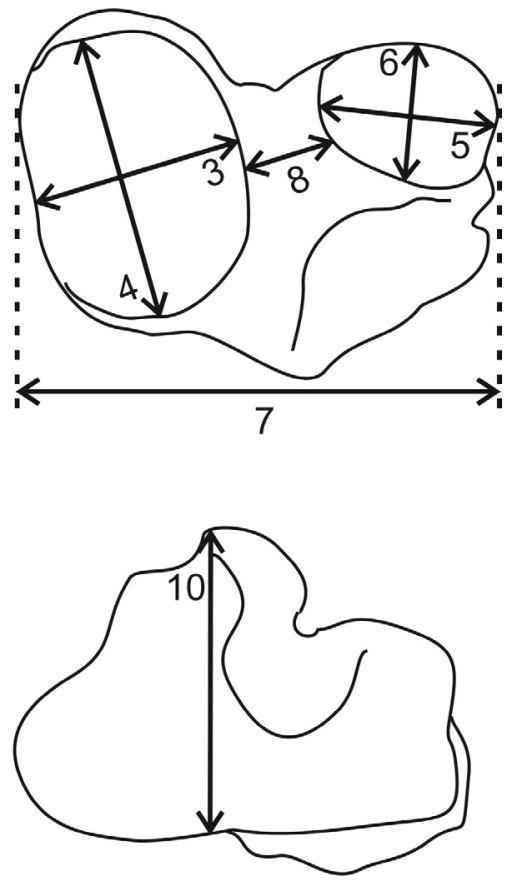


\subsection{INSTITUTIONAL ABBREVIATIONS}

AMNH, American Museum of Natural History, New York, USA; IHNFF, Instituto de Historia Natural, Fósil Foráneo, Paleontological Collection of the Museo de Paleontología "Eliseo Palacios Aguilera", Tuxtla Gutiérrez, Chiapas, México; IHNFG, Instituto de Historia Natural, Fósil Geográfico, Paleontological Collection of the Museo de Paleontología "Eliseo Palacios Aguilera", Tuxtla Gutiérrez, Chiapas, México; MCL, Museo de Ciências Naturais da Pontificia Universidade Católica de Minas Gerais, Brazil; MLP, Museo de La Plata, La Plata, Argentina; ROM, Royal Ontario Museum, Toronto, Canada.
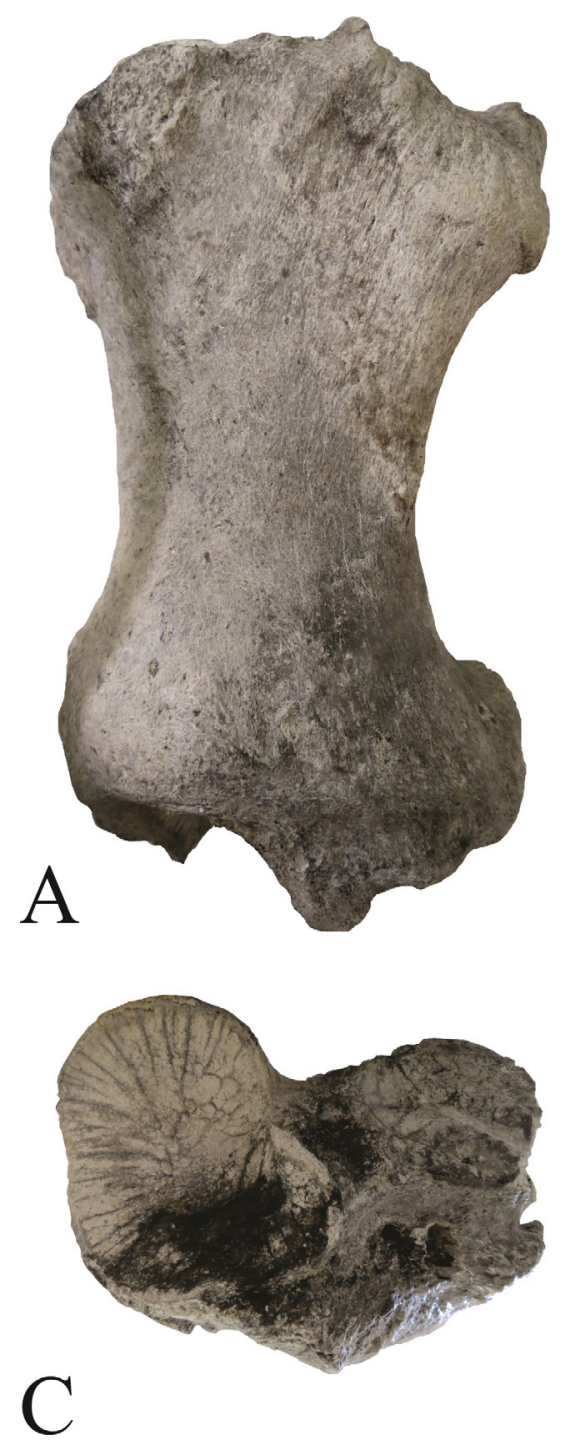

\section{Results}

\subsection{SYSTEMATIC PALEONTOLOGY}

Superorder Xenarthra Cope, 1889

Order Pilosa Flower, 1883

Infraorder Tardigrada Latham and

Davies in Forster, 1795

Family Mylodontidae Gill, 1872

Subfamily Mylodontinae Gill, 1872

Genus Paramylodon Brown, 1903

Paramylodon harlani (Owen, 1840)

Figure 3, Table 1
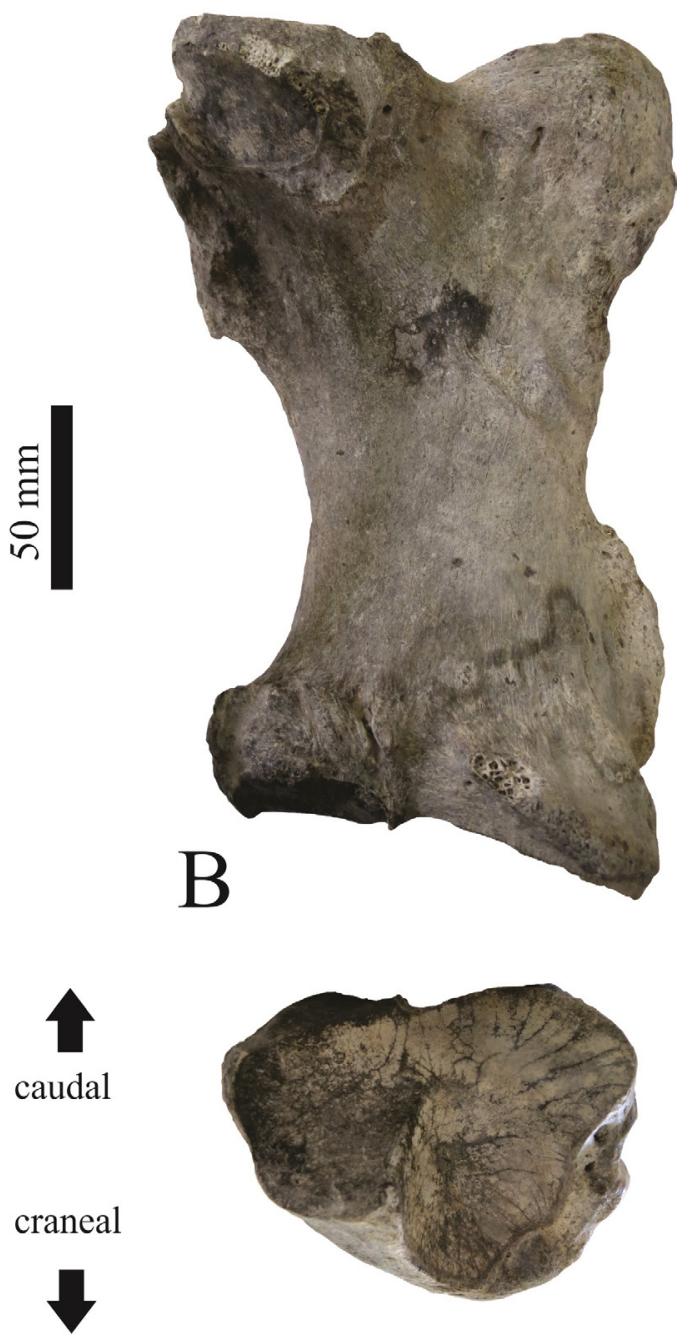

$\mathrm{D}$ 
Table 1. Measurements (in $\mathrm{mm}$ ) of the tibia IHNFF-180, from Valsequillo Basin, Puebla.

\begin{tabular}{lll} 
GL & 259 \\
\hline MnW & 96.2 & 94.5 \\
\hline MWMC & 97.1 \\
\hline AWMC & 69.3 \\
\hline MWLC & 71 \\
\hline AWLC & 166.1 \\
\hline PW & 29.2 \\
\hline ICW & 136.1 \\
\hline DW & 106 \\
\hline AWDAS &
\end{tabular}

\subsection{DESGRIPTION}

The tibia IHNFF-180 is complete, it shows signals of dragging at both ends. The epiphyses are fused, indicating that the specimen was an adult individual. The tibia is longer than wide, with the proximal and distal ends lateromedially expanded. The medial border of the diaphysis is almost straight, but the lateral border is medially curved (Figure 3A and 3B). Proximally, the lateral articular facet for the femoral condyle is flat and almost circular, while the medial articular facet is oval in shape and concave, with the long axis oriented in medial-lateral direction and is almost twice its size of the lateral articular facet. Both facets are separated by a sulcus in the intercondylar area (Figure 3C). Distally, the articular facet for the fibula is semicircular in shape, flat and lies laterally. The articular facet for the odontoid process of the astragalus is anteromedially positioned, it is wide and covers almost the entire distal area and its surface is concave. The discoid facet has a halfmoon shape and the surface is concave (Figure 3D). The lateral tibial condyle is prominent and bears two large foramina in the proximal surface. The medial malleolus is short and sturdy. One tendinal groove is located in the posterior side of the medial malleolus.

\section{Discussion}

\subsection{GOMPARISON AND TAXONOMIG ASSESSMENT}

A comparison between Eremotherium laurillardi tibiae IHNFG-2715 and specimens reported on the literature (De Iullis, 1996) with IHNFF-180, show a significant difference in size, as the tibia of $E$. laurillardi is twice the size of the studied specimen (Table 2, Figure 4). The tibia of E. laurillardi is long and thin in the midshaft, like that of Nothrotheriops shastensis and Megalonyx jeffersonii. Additionally, the medial border of the diaphysis is less concave in $E$. laurillardi than in IHNFF-180.

The tibia IHNFF-180 is also easily distinguished from the tibiae of $\mathcal{N}$. shastensis and M. jeffersonii reported in the literature (Stock, 1925). In IHNFF-180 the mediolateral midshaft of the diaphysis is wider than in $\mathcal{N}$. shastensis and $M$. jeffersoni, but it has the same proportions of Paramylodon harlani (Table 2). This robustness seems to be typical of mylodontine mylodonts, as can be seen in the South American taxa Simomylodon uccasamamensis, Glossotherium tropicorum and $G$. phoenesis (Saint-Andre et al., 2010; De Iuliis et al., 2017; Cartelle et al., 2019).

The tibia, IHNFF-180, differs from those of $\mathcal{N}$. shastensis and $M$. jeffersonii in that it bears one tendinal groove in the posterior side of the medial malleolus, while in $\mathcal{N}$. shastensis and $M$. jeffersonii two grooves are present in this region (Stock, 1925; Tomiya et al., 2001). The lateral tibial condyle is less prominent; the medial malleolus is very short and the articular surface for the astragalus is wider (Leidy, 1885, plate XII, figs. 1-3; Stock, 1925, plate XIV, figs. 1, 1a, 1b, 2, 3).

We noted a major difference between IHNFF-180 and Glossotherium phoenesis (Cartelle et al., 2019) and G. robustum. In posterior view, the lateral epicondyle in the tibia IHNFF-180 is more prominent and extends more upwardly than the tibiae of G. phoenesis and G. robustum. The lateral tibial condyle is oriented more upward in G. phoenesis than in IHNFF-180 and G. robustum. In proximal view, the articular medial facet for femoral condyle of IHNFF-180 is wider in the 
Table 2. Comparative measurements of IHNFF-180 and selected Late Pleistocene large-sized ground sloth taxa from North America and South America.

\begin{tabular}{|c|c|c|c|c|c|c|c|}
\hline Taxon & GL & PW & DW & MnW & $\begin{array}{c}\text { Ratio } \\
\text { MnW /GL }\end{array}$ & Locality & Source \\
\hline $\begin{array}{l}\text { Paramylodon harlani } \\
\text { (IHNFF-180) }\end{array}$ & 259 & 136 & 166.1 & 96.2 & 0.37 & $\begin{array}{c}\text { Valsequillo, } \\
\text { Puebla, Mexico }\end{array}$ & This work \\
\hline $\begin{array}{l}\text { Paramylodon harlani (type } \\
\text { specimen AMNH 2780) }\end{array}$ & 287 & 180.7 & 149.2 & 94.5 & 0.32 & $\begin{array}{c}\text { Hay Spring, Nebraska, } \\
\text { USA }\end{array}$ & This work \\
\hline $\begin{array}{l}\text { Paramylodon harlani } \\
(\mathrm{n}=32)^{*}\end{array}$ & 247.3 & 185.2 & 142.5 & 93.8 & 0.38 & $\begin{array}{l}\text { Rancho La Brea, } \\
\text { California, USA }\end{array}$ & Stock, 1925 \\
\hline Paramylodon harlani $(\mathrm{n}=4)^{*}$ & 270.3 & 206.6 & 152.5 & 106.8 & 0.39 & $\begin{array}{c}\text { Tlalnepantla, Mexico } \\
\text { State, Mexico }\end{array}$ & $\begin{array}{c}\text { Cristín- } \\
\text { Ponciano, } 2003\end{array}$ \\
\hline $\begin{array}{l}\text { Nothrotheriops shastensis } \\
(\mathrm{n}=2)^{*}\end{array}$ & 312.5 & 184.4 & 136 & 61.7 & 0.21 & $\begin{array}{l}\text { Rancho La Brea, } \\
\text { California USA }\end{array}$ & Stock 1925 \\
\hline $\begin{array}{l}\text { Megalonyx jeffersonii } \\
(\mathrm{n}=6)^{*}\end{array}$ & 302.1 & 182.6 & 144 & 75.6 & 0.25 & Several localities & Fields 2010 \\
\hline Eremotherium laurillardi* & 555 & 315 & 213 & 110 & 0.19 & Several localities & De Iuliis 1996 \\
\hline Glossotherium tropicorum & $182^{* *}$ & 138.4 & $\begin{array}{c}114 * \\
*\end{array}$ & 70.7 & 0.38 & Corralito, Ecuador & $\begin{array}{c}\text { De Iuliis et al., } \\
2017\end{array}$ \\
\hline $\begin{array}{l}\text { Glossotherium phoenesis } \\
\text { (MCL 4303) }\end{array}$ & 251.4 & 168 & 125 & 78.7 & 0.32 & $\begin{array}{c}\text { Toca dos Ossos, Ouro } \\
\text { Branco, } \\
\text { Bahia, Brazil }\end{array}$ & $\begin{array}{l}\text { Cartelle et al., } \\
\qquad 2019\end{array}$ \\
\hline
\end{tabular}

Note: *The measurements represent the mean; ** estimated measurements.
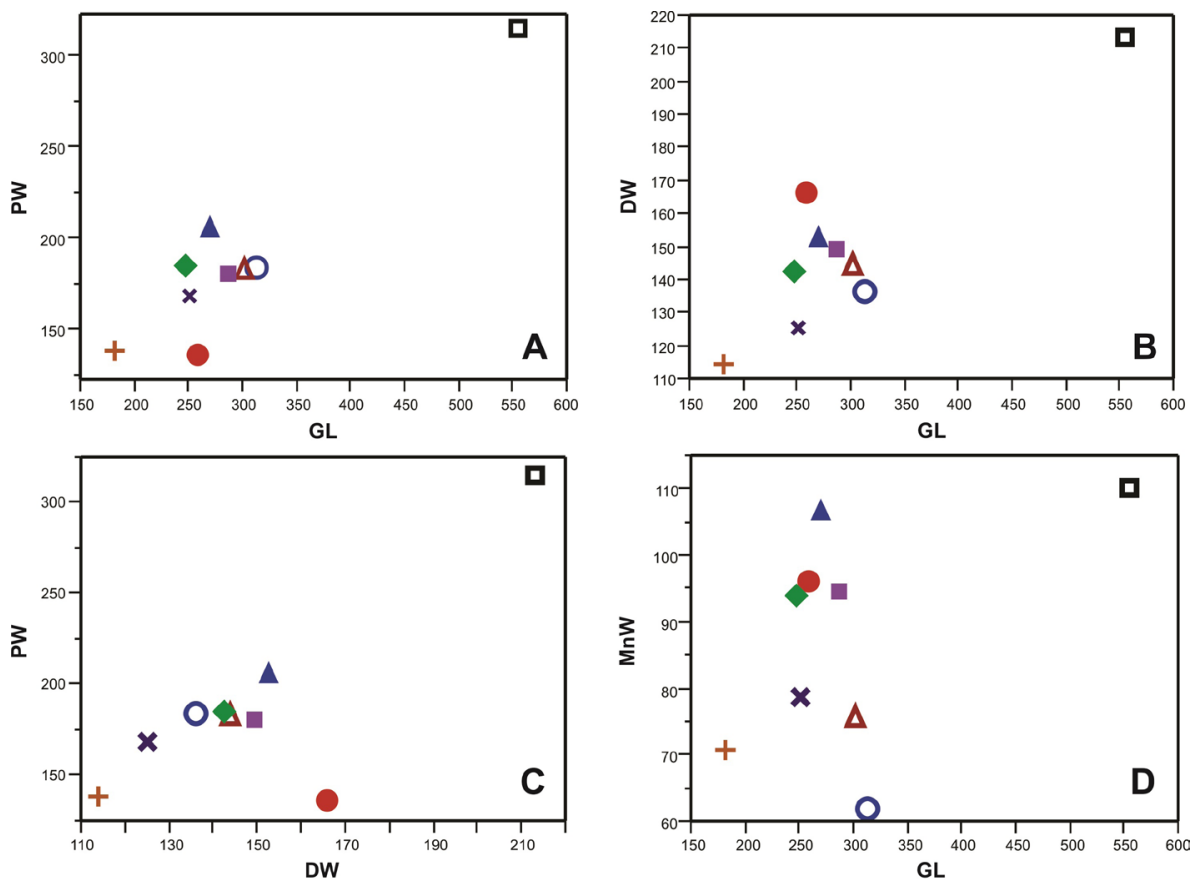

\begin{tabular}{|llll|}
\hline Symbols & Paramylodon RLB & $\times$ Glossotherium phoenesis & $\Delta$ Megalonyx jeffersonii \\
$\begin{array}{l}\text { Paramylodon Valsequillo } \\
\text { Paramylodon type }\end{array}$ & $\Delta$ Paramylodon Tlalnepantla & + Glossotherium tropicorum & 口 Eremotherium laurillardi \\
\hline
\end{tabular}

Figure 4 Bivariate plots of the measurements of selected Late Pleistocene large-sized ground sloth species from North and South America. A) GL vs PW; B) GL vs DW; C) DW vs PW and D) GL vs MnW. Abbreviations: DW, distal width; GL, greatest length; MnW, minimal width of the diaphysis; PW, proximal width; RLB, Rancho La Brea. 
cranial side than in $G$. phoenesis and $G$. robustum; on the contrary, the lateral articular facet is smaller in IHNFF-180 than in G. phoenesis and G. robustum. The anteroromedial border in $G$. phoenesis and $G$. robustum is more oblique than in IHNFF-180

In distal view, the articular facet for the odontoid process of the astragalus is oval in IHNFF-180 while in $G$. phoenesis and G. robustum is circular. The facet for the fibula is wider in IHNFF-180 than in G. phoenesis and G. robustum.

On the other hand, an objective comparison between the tibiae of Glossotherium tropicorum and IHNFF-180 was not possible, because both described tibiae, left and right (ROM 4237 and
ROM 4154, respectively) belong to a juvenile specimen and the epiphyses are missing (De Iuliis et al., 2017). However, in the illustrated left tibiae (ROM 4154) (De Iuliis et al., 2017, fig. $8 \mathrm{~K})$ it is possible to note some minor differences with IHNFF-180. In ROM 4154 the medial side of the diaphysis is more inwardly curved and the proximal end is wider than in IHNFF-180. However, we do not discard the possibility that these minor differences may be a consequence of the ontogenetic disparity between the specimens.

The comparison between IHNFF-180 and the tibiae of the type specimen Paramylodon nebraskensis (=Paramylodon harlani) did not show any

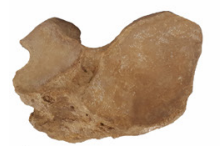

A

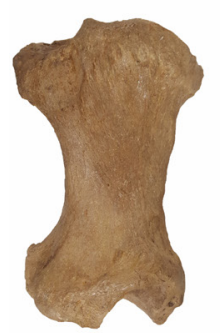

C
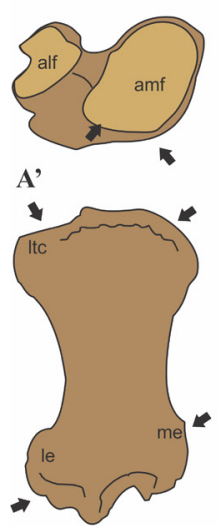

C'

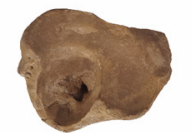

B

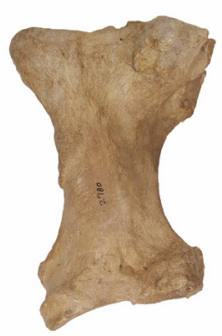

D

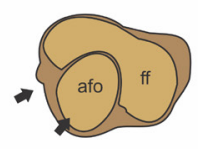

B'

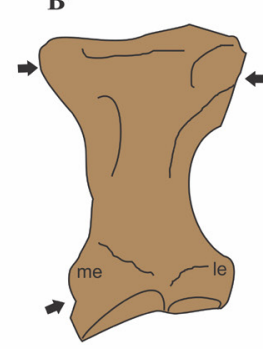

D'

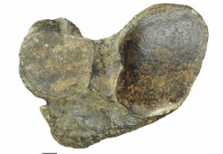

E

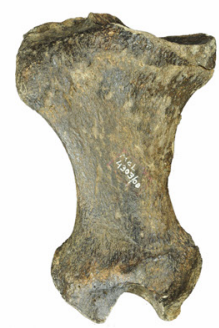

G
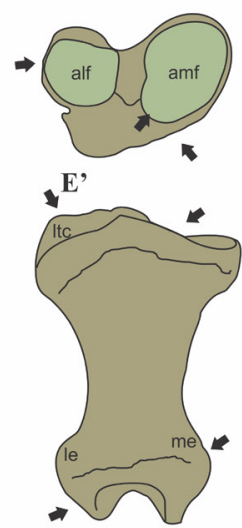

G'

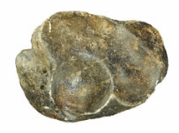

F

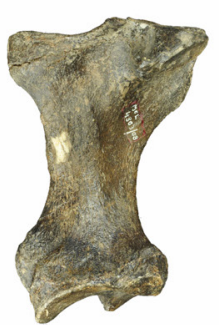

H
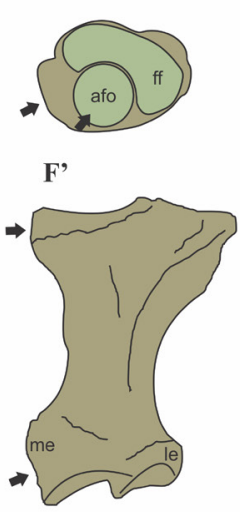

H'

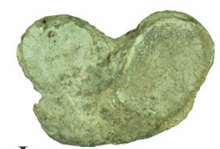

I

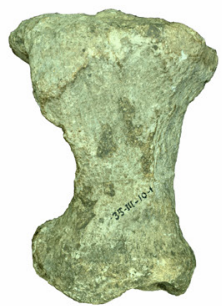

K

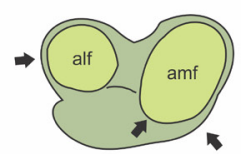

I'

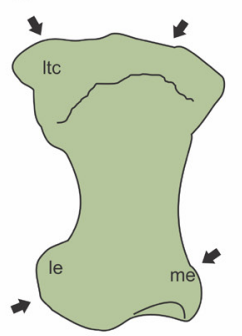

K'

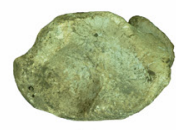

J

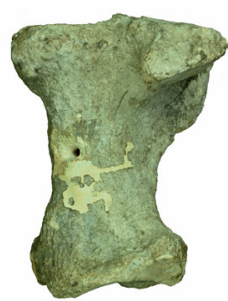

L

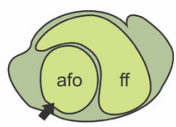

J'

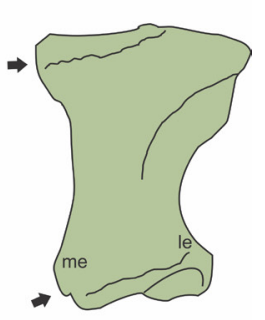

L'

Figure 5 Comparison of the right tibiae of Paramylodon harlani (type specimen AMNH 2780), Glossotherium phoenesis (type specimen MCL 4303, Cartelle et al., 2019) and G. robustum (specimen MLP 35-III-10-1). Photograph and schematic draws of the tibia of $P$. harlani in proximal (A, A'), distal (B, B'), cranial (C, C') and caudal (D, D') views; photograph and schematic draws of the tibia of G. phoenesis in proximal (E, E'), distal (F, F'), cranial (G, G') and caudal (H, H') views; and photograph and schematic draws of the tibia of G. robustum in proximal (I, I'), distal (J, J'), cranial (K, K') and caudal (L, L') views. Not to scale. The arrows show the principal morphological differences between both genera. Abbreviations: afo, articular facet for the odontoid process of astragalus; alf, articular lateral facet for femoral condyle; amf, articular medial facet for femoral condyle; ff, facet for the fibula; le, lateral epicondyle; Itc, lateral tibial condyle; me, medial epicondyle. 
morphological characteristic or measurements difference and are almost indistinguishable, therefore, our studied specimen can be confidently assigned to Paramylodon harlani.

McAfee (2007) mentioned that there does not exist any significant differences between the tibiae of Paramylodon and Glossotherium, except the size. We agree with McAfee (2007) that there are differences in the size between Paramylodon and Glossotherium (Figure 4, Table 2). However, the same morphological differences noted between the tibiae IHNFF-180 and the tibiae of Glossotherium phoenesis, G. robustum and G. tropicorum exist between the type specimen of Paramylodon and these
Glossotherium species. Therefore, we consider that there are morphological differences between both genera, and it is possible to differentiate between the species using the tibiae morphology (Figure 5).

\subsection{COMMENTS ON THE PALEOBIOGEOGRAPHY AND PALEOECOLOGY}

In Mexico, Paramylodon harlani had a wide geographic distribution, from the north (Baja California and Sonora) to the southeastern part of the country (Chiapas). One Irvingtonian and 19 Rancholabrean localities are recorded in Mexico (Figure 6); this contrast with the much larger

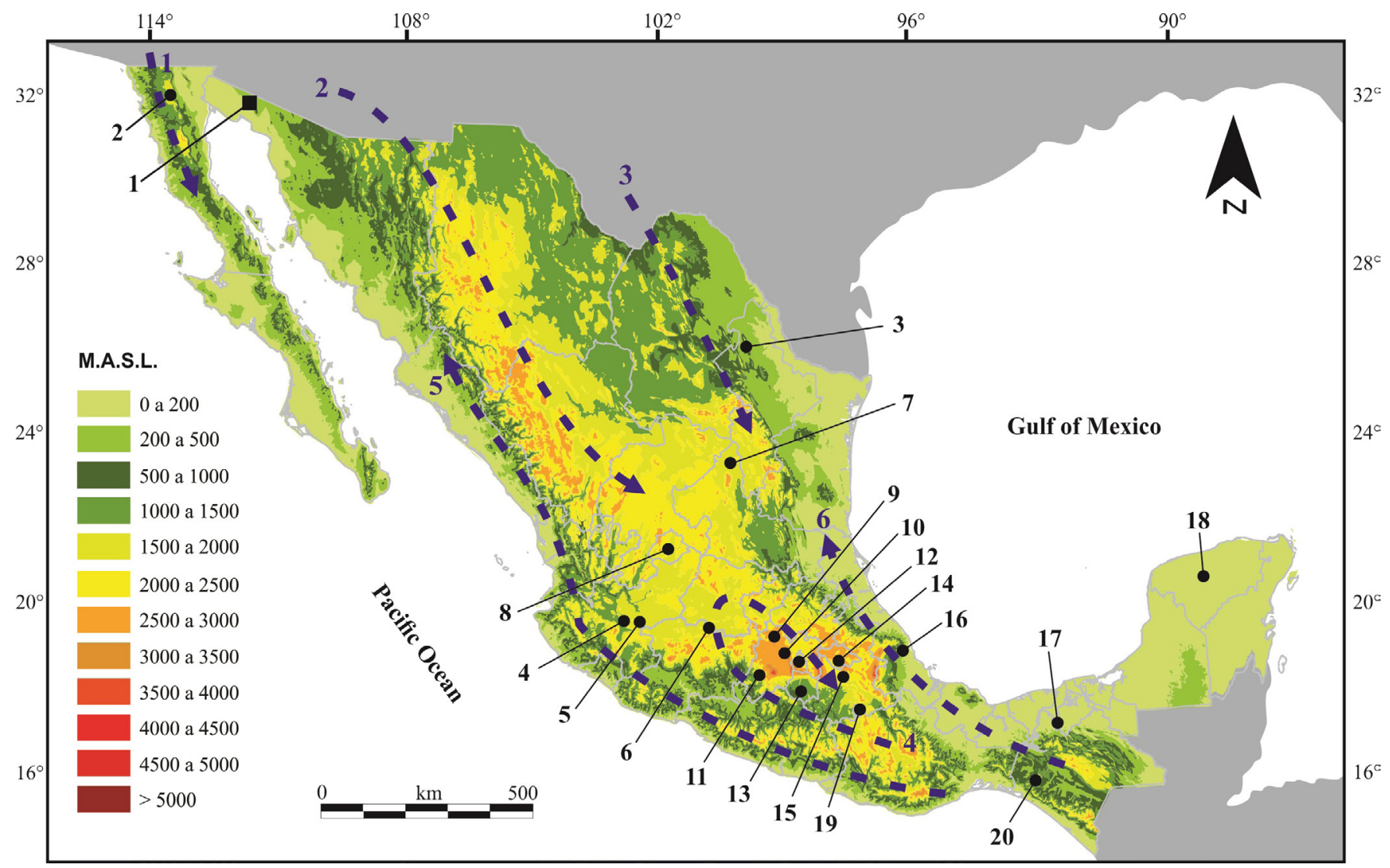

Figure 6 Localities with Paramylodon harlani specimens in Mexico (black numbers) and main biogeographic corridors (blue numbers). Black square Irvingtonian localities; black dots Rancholabrean localities. Localities: 1. El Golfo, Sonora; 2. Cabo Colnett, Baja California; 3. Bustamante Cave, Nuevo León; 4. Zocoalco, Jalisco; 5. Chapala, Jalisco; 6. La Cinta-Portalitos, Michoacán-Guanajuato; 7. El Cedral, San Luis Potosí; 8. Arroyo Cedazo, Aguascalientes; 9. Tequixquiac, Estado de Mexico; 10. Tlalnepantla, Mexico State; 11. Valle de Bravo, Mexico State; 12. Mexico City; 13. Chimalacatlán, Morelos; 14. Santa Cruz Aquiahuac, Tlaxcala; 15. Valsequillo, Puebla; 16. Morro de la Mancha, Veracruz; 17. Teapa, Tabasco; 18. Actun Spukil, Yucatán; 19. Santiago Chazumba, Oaxaca; 20. Villaflores, Chiapas. Major biogeographic corridors: temperate corridors: 1. Western US - Baja California, 2. Rocky Mountains - Sierra Madre Occidental, 3. Eastern US - Sierra Madre Oriental, 4. Transvolcanic Belt - Sierra Madre del Sur. Tropical corridors: 5. Sonora - Central America Pacific lowlands and 6. Tamaulipas - Central America Gulf Lowlands. 
Table 3. Altitude of the localities with records of Paramylodon harlani in Mexico.

\begin{tabular}{|l|l|r|}
\hline Id & Locality & Altitude (m.a.s.l.) \\
\hline 1 & El Golfo, Sonora & 7 \\
\hline 2 & Cabo Colnett, Baja California & 45 \\
\hline 3 & Bustamante Cave, Nuevo León & $1500-2200$ \\
\hline 4 & Zocoalco, Jalisco & $1358-1500$ \\
\hline 5 & Chapala, Jalisco & 1540 \\
\hline 6 & La Cinta-Portalitos, Michoacán-Guanajuato & $1750-2350$ \\
\hline 7 & El Cedral, San Luis Potosí & 1750 \\
\hline 8 & Arroyo Cedazo, Aguascalientes & 1890 \\
\hline 9 & Tequixquiac, Mexico State & $2100-2600$ \\
\hline 10 & Tlalnepantla, Mexico State & 2240 \\
\hline 11 & Valle de Bravo, Mexico State & 1850 \\
\hline 12 & Mexico City & 2250 \\
\hline 13 & Chimalacatlán, Morelos & 915 \\
\hline 14 & Santa Cruz Aquiahuac, Tlaxcala & 2220 \\
\hline 15 & Valsequillo, Puebla & 2100 \\
\hline 16 & Morro de la Mancha, Veracruz & 8 \\
\hline 17 & Teapa, Tabasco & 72 \\
\hline 18 & Actun Spukil, Yucatán & 38 \\
\hline 19 & Santiago Chazumba, Oaxaca & 1710 \\
\hline 20 & Villaflores, Chiapas & 560 \\
\hline
\end{tabular}

number of localities from USA (see McDonald, 2012). Most of the localities are in the TransMexican Volcanic Belt, between 1500 to 2200 m.a.s.l. (Table 3), so altitude is not a limiting factor for the distribution of $P$. harlani. The Valsequillo Basin is at 2,100 m.a.s.l. In the USA, the species has been recorded also at high elevations, such as in Silver Creek local fauna of Utah (1,952 m.a.s.l.) and at the Magna Site, Saguache County, Colorado (2,330 m.a.s.l.) (McDonald et al., 2004). Only three localities are located in the north, and three in southeastern Mexico (Figure 6), at lower altitudes (0 to 1000 m.a.s.l.). The biogeographic corridors (Figure 6) that $P$. harlani probably used to move through Mexico include the Eastern US - Sierra Madre Oriental, Western US - Baja California, Rocky Mountains - Sierra Madre Occidental, Transvolcanic Belt - Sierra Madre del Sur temperate corridors, and Tamaulipas Central America Gulf Lowlands, and Sonora - Central America Pacific lowlands tropical corridors (sensu Ceballos et al., 2010).

Historically, P. harlani has been considered a grazer (Brown, 1903; Webb, 1978), browser (Dalquest and Schultz, 1992) or mixed feeder (Stock, 1925; Naples, 1989); even, it has been referred as granivore with a diet dominated by grasses and sedges (McDonald and Pelikan, 2006). Recent work has inferred the diet of $P$. harlani based on stable isotopes. Coltrain et al. (2004) using stable isotopes of carbon $\left(\delta^{13} \mathrm{C}\right)$ and nitrogen $\left(\delta^{15} \mathrm{~N}\right)$ of specimens from Rancho La Brea, California, showed that they were browsers. Rues (2005) using $\delta^{13} \mathrm{C}$ from teeth of specimens from Ingleside fauna, San Patricio County, Texas, inferred a mixed diet, but the values found $(-4 \% 0)$ are near to values indicative of a grazer. In Mexico, Pérez-Crespo et al. (2014) inferred the diet of one specimen of $P$. harlani from Valsequillo using $\delta^{13} \mathrm{C}$ and showed that this individual was a grazer. The dietary flexibility of Paramylodon indicates that it could inhabit different environments, from grasslands to more wooded areas.

The reconstruction of the dietary habits of some herbivorous mammals from El Cedral, La Cinta-Portalitos and Villaflores, localities with records of Paramylodon, indicate that these species lived in areas with heterogenous vegetation dominated by grasslands (Pérez-Crespo et al., 2015; Marín-Leyva et al., 2016; Díaz-Sibaja et al., 2018). In the same way, in the Valsequillo basin a mixture of grazer, browser and mixed feeders herbivores 
has been reported (Pérez-Crespo et al., 2014). So, heterogenous vegetation has been proposed for the area. The paleoclimatic reconstruction of the Valsequillo basin using stable isotopes of $\delta^{18} \mathrm{O}$ and $\delta^{13} \mathrm{C}$ extracted from the shells of terrestrial and freshwater gastropods from Barranca Caulapan shows that 35,000 years ago, the climate in that region of Puebla was very similar to the present one. Between 35,000 and 20,000 years wet conditions increased, and later, after 20,000 years, moisture raised again (Stevens et al., 2012). This shows high climatic variability in the Valsequillo Basin through time, which in turn influenced the vegetation. Therefore, Paramylodon harlani should have had a generalist diet to be adapted to these conditions.

The paleoclimatic and paleoenvironmental conditions reconstructed for some localities in Mexico agree with the habitats previously proposed to $P$. harlani from USA, such as Shonto and Springerville localities in Arizona, West Tarkio Creek in Iowa, and Doeden gravel pit, Yellowstone River Valley in Montana (e.g. McDonald et al. 2004; Wilson et al. 2005; McDonald 2012).

\section{Conclusions}

The examination of the tibia IHNFF-180 allows us to identify it as Paramylodon harlani, based on the morphological and meristic characteristics. This is the first specimen formally described for this area, although there is a second unpublished record of the species for the Valsequillo Basin.

The paleoenvironmental and paleoclimatic inference of some localities in Mexico where $P$. harlani occurred, indicate heterogenous vegetation dominated by grasslands, and agrees with the proposed habitats for the species found in more northern localities in the USA. This indicates that $P$. harlani could inhabit different environments, from grasslands to more wooded areas, and this adaptation allowed it to extend from the north to the southeast of Mexico.

The comparison between the tibiae IHNFF-180, the type specimen of $P$. nebraskensis,
G. tropicorum, G. robustum and $G$. phoenesis, revealed morphological differences between Paramylodon and Glossotherium, contributing to the discussion about the morphological differentiation between both genera.

\section{Acknowledgements}

We thank Abraham López Rojas for the support in the fieldwork; Joaquín Eng Ponce and the wikipaleo community for sharing bibliography, as well as Miguel Díaz de León Muñoz for the photograph of the type specimen of Paramylodon nebraskensis. François Pujos provided the photographs of Glossotherium phoenesis and Castor Cartelle the permission to used it; Alberto Boscaini provided the photographs of G. robustum. We thank to H. Gregory McDonald and one anonymous reviewer for the comments that improved the manuscript.

\section{References}

Armenta Camacho, J., 1978, Vestigios de labor humana en huesos de animales extintos de Valsequillo, Puebla, México: Consejo Editorial del Gobierno del Estado de Puebla. Puebla, Mexico.

Arroyo-Cabrales, J., Corona-M., E., Polaco, O.J., Cruz Silva, J.A., Córdova, M., Canto, G., Basante, O., 2004, Recent excavations in the Cueva Encantada, Chimalacatlán, Morelos, México: Current Research in the Pleistocene, 21, 9-11.

Arroyo-Cabrales, J., Polaco, O.J., 2003, Caves and the Pleistocene vertebrate paleontology of Mexico, in Schubert, B.W., Mead, J.I., Graham, R.W. (eds), Ice Age cave faunas of North America: United States of America, Indiana University Press, 273-291.

Barrañón-Salmón, A.E., Pérez-Rodríguez, V.J., 2017, Identificación de perezoso fósil del Morro de la Mancha, Veracruz (abstract), 
in XV Congreso Nacional de Paleontología: San Luis Potosí, Paleontología Mexicana, Special 2, 12.

Brown, B., 1903, A new genus of ground sloth from the Pleistocene of Nebraska: Bulletin American Museum of Natural History, 19, 569-583.

Carbot-Chanona, G., Gómez-Pérez, L.E., 2014, Adición al registro de megamamíferos del Pleistoceno tardío de Chiapas (abstract), in II Simposio de Paleontología en el sureste de México: Puerto Escondido, Oaxaca, Universidad del Mar, 24.

Cartelle, C., De Iuliis, G., Boscaini, A., Pujos, F., 2019, Anatomy, possible sexual dimorphism, and phylogenetic affinities of a new mylodontine sloth from the late Pleistocene of intertropical Brazil: Journal of Systematic Palaeontology, 17(23), 1957-1988. https:// doi.org/10.1080/14772019.2019.1574406

Ceballos, G., Arroyo-Cabrales, J., Ponce, E., 2010, Effects of Pleistocene environmental changes on the distribution and community structure of the mammalian fauna of Mexico: Quaternary Research, 73, 464-473. https:// doi.org/10.1016/j.yqres.2010.02.006

Churcher, C.S., 1984, Faunal correlations of Pleistocene deposits in western Canada, in Mahaney, W.C. (ed.), Correlation of Quaternary Chronologies: Norwich, England, GeoBooks, 145-158.

Coltrain, J.B., Harris, J.M., Cerling, T.E., Ehleringer, J.R., Dearing, M.-D., Ward, J., Allen,J., 2004, Rancho La Brea stable isotope biogeochemistry and its implications for the palaeoecology of late Pleistocene, coastal southern California: Palaeogeography, Palaeoclimatology, Palaeoecology, 205, 199- 219. https://doi.org/10.1016/j. palaeo.2003.12.008

Cope, E.D., 1889, The Edentata of North America: American Naturalist, 23, 657-664. https://doi.org/10.1086/274985

Cristín-Ponciano, A., 2003. Variación morfométrica in Paramylodon harlani Owen
(Xenarthra: Mylodontidae) de Tlalnepantla de Baz, Estado de México: Tlalnepantla, Estado de México, Universidad Nacional Autónoma de México, Unpublished bachelor thesis, 91 .

Cristín-Ponciano, A., Montellano-Ballesteros, M., 2008, Ontogenetic stages in Paramylodon harlani Owen from Tlalnepantla, Mexico: Current Research in the Pleistocene, 25, 165-167.

Dalquest, W.W., Schultz, G.E., 1992, Ice age mammals of northwestern Texas: Wichita Falls, Texas: Midwestern State University Press, 309 p.

De Iuliis, G., 1996, A systematic review of the Megatheriinae (Mammalia: Xenarthra: Megatheriidae): Toronto, Canada, University of Toronto, Ph.D. Dissertation, 781.

De Iuliis, G., Cartelle, G., McDonald, H.G., Pujos, F., 2017, The mylodontine ground sloth Glossotherium tropicorum from the late Pleistocene of Ecuador and Peru: Papers in Palaeontology, 3(4), 613-636. https://doi. org/10.1002/spp2.1088

Díaz-Sibaja, R., Jiménez-Hidalgo, E., PonceSaavedra, J., García-Zepeda, M.L., 2018, A combined mesowear analysis of Mexican Bison antiquus shows a generalist diet with geographical variation: Journal of Paleontology, 92(6), 1130-1139.https://doi. org/10.1017/jpa.2018.19

Eng-Ponce,J. 2018, Perezosos (Xenarthra: Folivora) y capibaras (Rodentia: Hydrochoerinae) del yacimiento pleistocénico (Rancholabreano) de la Cinta-Portalitos, MichoacánGuanajuato, México: Morelia, Michoacán, Universidad Michoacana de San Nicolás de Hidalgo, Unpublished bachelor thesis, 83.

Fields, S.E., 2010, The ground sloth: Megalonyx: Transactions of the American Philosophical Society, New Series, 100, 1-76.

Flower, W.H., 1883, On the arrangement of the orders and families of existing Mammalia: Proceedings of the Zoological Society of London, 1883, 178-186. 
Freudenberg, W., 1921, Geologie von Mexiko dargestellt nach der literatur und nach eigen Forschungen: Berlin, Germany, Verlag von Gebruder Borntraeger.

Gaudin, T.J., Croft, D.A., 2015, Paleogene Xenarthra and the evolution of South American mammals: Journal of Mammalogy, 96, 622-634. https://doi.org/10.1093/ jmammal/gyv073

Gill, T., 1872, Arrangements of the families of mammals, with analytical tables: Smithsonian Miscellaneous Collections, 11, 1-98.

Gonzalez, S., Huddart, D., Bennett, M., 2006, Valsequillo Pleistocene archaeology and dating: ongoingcontroversyin CentralMexico: World Archaeology, 38, 611-627. http:// dx.doi.org/10.1080/00438240600963155

Kraglievich, L.J., 1928, "Mylodon darwinii" Owen es la especie genotipo de "Mylodon" Ow. Rectificación de la nomenclatura genérica de los milodontes: Revista de la Sociedad Argentina de Ciencias Naturales, Physis, 9, 169-185.

Kurtén, B., Anderson, E., 1980, Pleistocene mammals of North America: New York, USA, Columbia University Press, 442.

Lambert, W.D., Holling, C.S., 1998, Causes of ecosystem transformation at the end of the Pleistocene: evidence from mammal bodymass distributions: Ecosystems, 1, 157-175.

Latham J., Davies, H., 1795, Faunula indica; appendix, in Forster, J.R. (ed.), Zoologia Indica, second edition: Editorial Secunda, $1-38$.

Leidy, J., 1855, A memoir of the extinct sloth tribe of North America: Smithsonian Contributions to Knowledge, 7, 1-68.

Lucas, S.G., 2008, Late Cenozoic vertebrate fossil assemblages from Jalisco, Mexico: New Mexico Museum of Natural History and Science Bulletin, 44, 51-64.

Marín-Leyva, A.H., Arroyo-Cabrales, J., GarcíaZepeda, M.L., Ponce-Saavedra, J., Schaaf, P., Pérez-Crespo, V.A., Morales-Puente, P., Cienfuegos-Alvarado, E., Alberdi, M.T., 2016, Feeding ecology and habitat of Late
Pleistocene Equus horses from west-central Mexico using carbon and oxygen isotopes variation: Revista Mexicana de Ciencias Geológicas, 33, 157-169.

Marshall, L.G., 1988, Land mammals and the Great American Interchange: American Scientist, 76, 380-388.

McAfee, R.K., 2007, Reassessing the taxonomy and affinities of the Mylodontinae sloths, Glossotherium and Paramylodon (Mammalia: Xenarthra: Tardigrada): Dekalb, Illinois, Northern Illinois University, Ph. D. Thesis, 162.

McAfee, R.K., 2009, Reassessment of the cranial characters of Glossotherium and Paramylodon (Mammalia: Xenarthra: Mylodontidae): Zoological Journal of the Linnean Society, 155, 885-903. https://doi. org/10.1111/j.1096-3642.2008.00468.x

McDonald, H.G., 1995, Gravigrade xenarthrans from the early Pleistocene Leisey Shell Pit 1A, Hillsborough County, Florida. in Hulbert, Jr., R.C., Morgan, G.S., Webb, D. (eds.), Paleontology and geology of the Leisey Shell Pits, early Pleistocene of Florida, Part II: Bulletin of the Florida Museum Natural History, 37, 345-373.

McDonald, H.G., 2002, Fossil Xenarthra of Mexico: a review, in Montellano Ballesteros, M., Arroyos Cabrales, J. (coord.), Avances en los estudios paleomastozoológicos: Ciudad de Mexico, Instituto Nacional de Antropología e Historia., 227-248.

McDonald, H.G., 2012, Harlan's ground sloth (Paramylodon harlani) (Xenarthra: Mylodontidae) from the Late Pleistocene (Rancholabrean) of Iowa: The Journal of the Iowa Academy of Science, 119, 16-21.

McDonald, H.G., Agenbroad, L.D., Haden, C.M., 2004, Late Pleistocene mylodont sloth Paramylodon harlani (Mammalia: Xenarthra) from Arizona: The Southwestern Naturalist 49(2), 229238. https://doi.org/10.1894/00384909(2004)049<0229:lpmsph>2.0. со;2 
McDonald, H.G., Carranza-Castañeda, O., 2017, Increased xenarthran diversity of the Great American Biotic Interchange: a new genus and species of ground sloth (Mammalia, Xenarthra, Megalonychidae) from the Hemphillian (late Miocene) of Jalisco, Mexico: Journal of Paleontology, 91, 10691082. https://doi.org/10.1017/jpa.2017.45

McDonald, H.G., De Iuliis, G., 2008, Fossil history of sloths, in Vizcaíno, S.F., Loughry, W.J. (eds.), The Biology of the Xenarthra: Gainesville, Florida, University Press of Florida., 39-55.

McDonald, H.G., Naples, V.L., 2008, Xenarthra, in Janis C.M., Gunnell, G.F., Uhen, M.D. (eds.), Evolution of Tertiary Mammals of North America, Volume 2: Small Mammals, Xenarthrans, and Marine Mammals: Cambridge, UK, Cambridge University Press, 147-160. https://doi.org/10.1017/ cbo9780511541438.011

McDonald. H.G., Pelikan, S., 2006, Mammoths and mylodonts: Exotic species from two different continents in North American Pleistocene faunas: Quaternary International 142-143, 229-241. https:// doi.org/10.1016/j.quaint.2005.03.020

McKenna, M.C., Wyss, A.R., Flynn, J.J., 2006, Paleogene pseudoglyptodont xenarthrans from Central Chile and Central Patagonia: American Museum Novitates, 3536, 1-18. https://doi.org/10.1206/0003$0082(2006) 3536$ [ $1: \mathrm{ppxfcc}] 2.0$. co;2

Metcalfe, S.E., Leng, M.J., Kirby,J.R., Huddart D., Vane C.H., Gonzalez, S., 2016, Early-Mid Pleistocene environments in the Valsequillo Basin, Central Mexico: a reassessment: Journal of Quaternary Science, 31, 325-336. https://doi.org/10.1002/jqs.2851

Monés, A., 1971, Observaciones sobre la familia Mylodontidae (Edentata, Megalonychoidea) en México: Paleoecologia, 6, 1-22.

Mooser, O., Dalquest, W.W., 1975, Pleistocene mammals from Aguascalientes, Central Mexico: Journal of Mammalogy, 56,
781-820. https://doi.org/10.2307/1379653

Muelleried, F.K.G., 1934, Sobre un gravido gigantesco (Mylodon) encontrado en el Valle de México: Anales del Instituto de Biología, 5, 223-236.

Naples, V.L., 1989, The feeding mechanism in the Pleistocene ground sloth, Glossotherium: Contributions in Science, 415, 1-23.

Owen, R., 1840, The zoology of the voyage of the H.M.S. Beagle, 1832-1836. Part 1.,Fossil mammals: London, UK.

Pérez-Crespo, V.A., Arroyo-Cabrales, J., Alva-Valdivia, L.M., Morales-Puente, P., Cienfuegos-Alvarado, E., Otero, F.J., Ochoa-Castillo, P., 2014, La paleodieta de cinco especies de mamíferos herbívoros rancholabreanos de Valsequillo (Puebla, México): Revista Chilena de Antropología, 30, 76-82. https://doi. org/10.5354/0719-1472.2014.36273

Pérez-Crespo, V.A., Carbot-Chanona, G., Morales-Puente, P., Cienfuegos-Alvarado, E., Otero F.J., 2015, Paleoambiente de la Depresión Central de Chiapas, con base en isótopos estables de carbono y oxígeno: Revista Mexicana de Ciencias Geológicas, 32, 273-282.

Pichardo, M., 1997, Valsequillo biostratigraphy: New evidence for Pre-Clovis date: Anthropologischer Anzeiger, 55, 233-246. https://doi.org/10.1127/ anthranz/55/1997/233

Polaco-Ramos, O.J., 1981, Restos fósiles de Glossotherium y Eremotherium (Edentata) en México, in Anais II Congreso LatinoAmericano Paleontologia: Porto Alegre, Instituto Nacional de Antropología e Historia, 819-833.

RuesJr., D.R., 2005, Diet of Pleistocene Paramylodon harlani (Xenarthra: Mylodontidae): review of methods and preliminary use of carbon isotopes: The Texas Journal of Science, 57, 329-344.

Saint-André, P.-A., Pujos, F., Cartelle, C., De Iuliis, G., Gaudin, T.J., McDonald, H.G., Mamani Quispe, B., 2010, Nouveaux 
paresseux terrestres (Mammalia, Xenarthra, Mylodontidae) du Néogène de l'Altiplano bolivien: Geodiversitas, 32, 255-306. https://doi.org/10.5252/g2010n2a4

Simpson, G.G., 1945, The principles of the classification and a classification of mammals: Bulletin of the American Museum of Natural History, 85, 1-350.

Smith, F.A., Lyons, S.K., Ernest, S.M., Jones, K.E., Kaufman, D.M., Dayan, T., Haskell, J.P., 2003, Body mass of late Quaternary mammals: Ecology, 84 (12), 3403. https:// doi.org/10.1890/02-9003

Stevens, R.E., Metcalfe, S.E., Leng, M.J., Lamb, A.L., Sloane, H.J., Naranjo, E., González, S., 2012, Reconstruction of late Pleistocene climate in the Valsequillo Basin (Central Mexico) through isotopic analysis of terrestrial and freshwater snails: Palaeogeography, Palaeoclimatology, Palaeoecology, 319-320, 16-27. https://doi. org/10.1016/j.palaeo.2011.12.012

Stinnesbeck, S.R., Frey, E., Avíles Olguín, J., Stinnesbeck, W., Patrick, P., Mallison, H., González González, A., Aceves Núñez, E., Velázquez Morlet, A., Terrazas Mata, A., Benavente Sanvicente, M., Hering, F., Rojas Sandoval, C., 2017, Xibalbaonyx oviceps, a new megalonychid ground sloth (Folivora, Xenarthra) from the Late Pleistocene of the Yucatán Peninsula, Mexico, and its paleobiogeographic significance: Paläontologische Zeitschrift, 91, 245-271. https://doi.org/10.1007/ s12542-017-0349-5

Stinnesbeck, S.R., Frey, E., Stinnesbeck, W., 2018, New insights on the paleogeographic distribution of the Late Pleistocene ground sloth genus Xibalbaonyx along the Mesoamerican Corridor: Journal of South American Earth Sciences, 85, 108-120. https://doi.org/10.1016/j. jsames.2018.05.004

Stock, C., 1917, Further observations on the skull structure of mylodont sloths from Rancho La
Brea: University of California Publications, Bulletin of the Department of Geology, 10, 165-178.

Stock, C., 1925, Cenozoic gravigrade edentates of western North America with special reference to the Pleistocene Megalonychinae and Mylodontidae of Rancho La Brea: Carnegie Institute of Washington, 331, 1-206.

Tomiya, S., Mcguire, J.L., Dedon, R.W., Lerner, S.D., Setsuda, R., Lipps, A.N., Bailey, J.F., Hale, K.R., Shabel, A.B., Barnosky, A.D., 2001, A report on late Quaternary vertebrate fossil assemblages from the eastern San Francisco Bay region, California: PaleoBios, 30, 50-71.

Viñas-Vallverdú, R., Arroyo-Cabrales, J., RiveraGonzález, I.I., Rodríguez-Alvarez, X.P., Rubio-Mora, A., Eudave-Eusebio, I.N., Solís-Torres, O.R., Ardelean, C.F., 2017, Recent archaeo-palaeontological findings from Barranca del Muerto site, Santiago Chazumba, Oaxaca, México: Quaternary International, 431:168-180. http://dx.doi. org/10.1016/j.quaint.2015.04.055

Webb, S.D., 1978, The history of savanna vertebrates in the New World. Part II: South America and the Great Interchange: Annual Review of Ecology and Systematics, 9, 393-426. https://doi.org/10.1146/annurev. es.09.110178.002141

Webb, S.D., 1989, Osteology and relationships of Thinobadistes segnis, the first mylodont sloth in North America, in Redford, K.H., Eisenberg, J.F. (eds.), Advances in Neotropical Mammalogy: Gainesville, Sandhill Crane Press, 496-532.

Webb, S.D., 2006, The Great American Biotic Interchange: patterns and processes: Annals of the Missouri Botanical Garden, 93, 245-257.

Webb, S.D., Perrigo, S.C., 1985, New megalonychid sloths from El Salvador, in Montgomery, G. (ed.), The evolution and ecology of armadillos, sloths, and vermilinguas: Washington, D.C., Smithsonian Institution Press, 113-120. 
Wilson, M.G., McDonald, H.G., Hill, G.L., 2005, Fossil ground sloths, Megalonyx and Paramylodon (Mammalia: Xenarthra), from the Doeden Local Fauna, Montana: Current Research in the Pleistocene, 22, 83-85.
Woodburne, M.O., 1969, A late Pleistocene occurrence of the collared peccary, Dicotyles tajacu, in Guatemala: Journal of Mammalogy, 50, 121-125. https://doi. org/10.2307/1378637 